\title{
Ketaatan kapal pukat cincin (purse siner) di Pelabuhan Perikanan Pantai Tumumpa
}

\author{
Obedience of purse seiner at Tumumpa fishing port
}

\author{
Christina D. YuniniE*, ReVols D.CH. PAMiKIRAN, Fransisco. P.T. PANGAlila, \\ MARIANA E. KAYADOE dan JANNY F. POLII
}

Program Studi Pemanfaatan Sumberdaya Perikanan, Fakultas Perikanan dan Ilmu Kelautan, Universitas Sam Ratulangi Manado 95115

\begin{abstract}
This research is descriptive research which aims to determine the level of compliance of purse seiner based on the Technical Guidelines of the Directorate General of Marine Resources and Fisheries Supervision No. 143 of 2012. The data taken is all data from ships carried out on each observation month in September-December 2018 and JanuaryFebruary 2019. The results showed a comparison between the basic port suitability factors, the completeness of ship documents, fishing operations days, and the suitability of the number of fish with fish storage capacity classified as good with a percentage of compliance of 76-100\%. For obedient vessels, temporary appreciation is given which is not given sanctions in accordance with applicable regulations.
\end{abstract}

Keywords: Purse Seiner; Surveillance; suitability; document; Tumumpa

\begin{abstract}
ABSTRAK
Penelitian ini adalah penelitian deskriptif yang bertujuan untuk mengetahui tingkat kepatuhan kapal pukat cincin berdasarkan Juknis Ditjen Pengawasan Sumberdaya Kelautan dan Perikanan No 143 tahun 2012. Data yang diambil adalah semua data dari kapal yang beroperasi pada setiap bulan pengamatan yaitu pada bulan September-Desember 2018 dan Januari-Februari 2019. Hasil penelitian menunjukan bahwa tingkat kepatuhan terhadap faktor kesesuaian pelabuhan pangkalan, kelengkapan dokumen kapal, hari operasi penangkapan ikan, dan keseuaian jumlah ikan dengan kapasitas penyimpanan ikan tergolong baik dengan nilai persentasi kepatuhan 76-100\%. Bagi kapal-kapal yang patuh diberikan apresiasi sedangkan yang tidak diberikan sanksi sesuai peraturan yang berlaku.
\end{abstract}

Kata-kata kunci: kapal pukat cincin; pengawasan; kesesuaian; dokumen; tumumpa

\section{PENDAHULUAN}

Sektor kelautan dan perikanan yang merupakan salah satu pendukung ekonomi Negara indonesia yang memiliki perairan yang sangat penting bagi sumber devisa Negara. Potensi sumberdaya ikan dilaut Indonesia dapat di perkirakan 6,5 juta ton pertahun, tersebar diperairan wilayah indonesia dan perairan zona ekonomi eksklusif (ZEE).

Illegal fishing yaitu penaangkapan ikan tanpa izin, penangkapan ikan dengan memggunakan izin terlarang, penangkapan ikan dengan jenis (spesies) yang tidak sesuai dengan izin. Penangkapam secara illegal merupakan persoalan terbesar, dan upaya untuk menyelesaikan masalah sangat rumit dikarenakan melibatkan banyak pihak. Ketetapan untuk tetap menjaga potensi-potensi kelautan dan perikanan serta ketetapan aturan dibentuknya direktorat jenderal pengawasan sumberdaya kelautan dan perikanan (Ditjen PSDKP) lembaga pemerintah yang berada dibawah pengelolaan kementrian kelautan dan perikanan yang dibentuk pada tanggal 23 November tahun 2000. Ditjen PSDKP bertanggungjawab untuk melakukan pengawasan dibidang sumberdaya kelautan dan perikanan.

*Penulis untuk penyuratan; email: christinayuninie@gmail.com 
Tujuan dari penelitian ini yaitu mengetahui tindakan-tindakan yang menyimpang dari ketaatan kapal pukat cincin (purse seiner) diatas 30 GT terhadap peraturan dan perundang-undangan yang berlaku dan mengetahui sejauh mana peringatan dan ketetapan hukum yang diberlakukan. Penelitian ini dilakukan dipelabuhan perikanan pantai Tumumpa dikantor pengawasan sumberdaya kelautan dan perikanan, dan penelitian dilaksanakan selama bulan Februari 2019.

\section{METODE PENELITIAN}

Metode yang digunakan yaitu metode deskriptif dimana metode yang dalam meneliti status objek pada masa sekarang dengan tujuan membuat gambaran secara sistematis, fenomena, membuat prediksi dan mendapatkan makna serta implikasi dari masalah yang diselidiki. Data yang dikumpulkan adalah data sekunder dari kegiatan kapal pukat cincin yang berukuran diatas 30 GT di pelabuhan perikanan pantai Tumumpa. Data yang dikumpulkan meliputi data keluar masuk kapal, data diambil selama 6 bulan terhitung bulan September 2018 - Februari 2019. Pengamatan terhadap kepatuhan dilihat berdasarkan Juknis
Ditjen PSDKP No.143 tahun 2012 yaitu tentang kesesuaian pelabuhan pangkalan, kesesuaian dokumen kapal, kesesuaian hari operasi, kesesuaian jumlah ikan dengan kapasitas penyimpanan ikan.

Data jumlah kapal pukat cincin yang beroperasi dan data pelabuhan pengamatan disajikan pada tabel 1 .

\section{Metode analisis data}

Tingkat kepatuhan kapal pukat cincin dianalisis berdasarkan rumusan yang dikemukakan oleh Surakhmad (1990) telah disesuaikan sebagai berikut :

Keterangan :

$$
P=\frac{n}{N} x 100 \%
$$

$\mathrm{P}$ : persentase kepatuhan terhadap aturan

$\mathrm{n}$ : jumlah realita kepatuhan kapal penangkap ikan

$\mathrm{N}$ : jumlah seluruh kapal penangkap ikan

Klasifikasi tingkat kepatuhan kapal penangkap ikan di atas $30 \mathrm{GT}$ dianalisis dengan menggunakan skala penilaian yang dikemukakan oleh Riduwan (2007) :

$$
\begin{aligned}
& 76 \%-100 \%=\text { Tinggi } \\
& 51 \%-75 \%=\text { cukup patuh } \\
& 26 \%-50 \%=\text { kurang patuh } \\
& 0 \%-25 \%=\text { Rendah }
\end{aligned}
$$

\begin{tabular}{|c|c|c|c|c|c|c|c|c|}
\hline \multirow{3}{*}{ No } & \multirow{3}{*}{ Ukuran Kapal } & \multicolumn{6}{|c|}{ Jumlah Kapal } & \multirow{3}{*}{$\begin{array}{c}\text { Jumlah } \\
\text { Rata-Rata }\end{array}$} \\
\hline & & \multicolumn{4}{|c|}{2018} & \multicolumn{2}{|c|}{2019} & \\
\hline & & September & Oktober & November & Desember & Januari & Februari & \\
\hline 1 & 30- 50 GT & 28 & 26 & 28 & 30 & 26 & 25 & 163 \\
\hline \multirow[t]{2}{*}{2} & $>50 \mathrm{GT}$ & 7 & 9 & 7 & 7 & 5 & 5 & 40 \\
\hline & Total & 35 & 35 & 35 & 37 & 31 & 30 & 203 \\
\hline
\end{tabular}

Tabel 1. Jumlah kapal berdasarkan GT dan bulan pengamatan.

\section{HASIL DAN PEMBAHASAN}

\section{Tingkat kepatuhan terhadap peraturan perundang-undangan.}

Tingkat kepatuhan kapal pukat cincin berukuran lebih dari 30 GT yang berpangkalan di pelabuhan perikanan pantai Tumumpa terhadap peraturan perundang- undangan dibagi dalam dua kategori yaitu 30-50 GT dan >50 GT. Hasil analisis persentase kepatuhan terhadap peraturan PSDKP no. 143 tahun 2012 yang meliputi kesesuaian pelabuhan pangkalan, kesesuaian dokumen kapal, kesesuaian hari operasi penangkapan, kesesuaian jumlah ikan dengan kapasitas penyimpanan disajikan pada tabel 2 dan 3 serta pada gambar 1dan 2.
Berdasarkan tabel 2 dan 3 dapat dilihat bahwa ketidakpatuhan kapal pukat cincin ukuran diatas 30 GT yang berpangkalan di pelabuhan perikanan pantai Tumumpa berada dalam tingkat kepatuhan yang baik. Dari keempat kategori pelanggaran pada tabel 2 dan 3 bisa dilihat dimana kategori paling banyak yaitu seringnya pelaku, nahkoda, ataupun pemilik kapal tidak langsung mengurus perpanjangan dokumen kapal seperti Surat ijin usaha perikanan (SIUP), Surat ijin penangkap ikan (SIPI) dan surat keterangan aktif transmiter (SKAT) seperti yang tercantum dalam PERMEN KP. No 30 tahun 2012.

Keterlambatan pengurursan ini membuat kapal yang bersangkutan batal untuk melakukan kegiatan penangkapan ikan. Kategori ke 2 yang dilanggar 


\section{C.D. Yuninie dkk.}

yaitu aspek hari operasi dimana banyak nahkoda atau pemilik kapal yang terlambat datang melapor dan ada beberapa kapal yang melakukan docking.
Jika dilihat dari kepatuhan, ada 2 kategori yang sangat bagus, yaitu kesesuaian pelabuhan pangkalan dan kapasitas penyimpanan ikan.

Tabel 2. Persentase kepatuhan aturan dari kapal pukat cincin 30- 50 GT periode September 2018- Februari 2019.

\begin{tabular}{|c|c|c|c|c|c|c|}
\hline \multirow{3}{*}{ Uraian Aturan } & \multicolumn{6}{|c|}{ Persentase Kepatuhan (\%) } \\
\hline & \multicolumn{4}{|c|}{2018} & \multicolumn{2}{|c|}{2019} \\
\hline & September & Oktober & November & Desember & Januari & Februari \\
\hline $\begin{array}{l}\text { Kesesuaian pelabuhan } \\
\text { pangkalan }\end{array}$ & $100 \%$ & $100 \%$ & $100 \%$ & $100 \%$ & $100 \%$ & $100 \%$ \\
\hline Kesesuaian dokumen kapal & $89 \%$ & $92.30 \%$ & $96.42 \%$ & $96,66 \%$ & $84.61 \%$ & $92 \%$ \\
\hline $\begin{array}{l}\text { Hari operasi penangkapan } \\
\text { ikan }\end{array}$ & $100 \%$ & $100 \%$ & $100 \%$ & $100 \%$ & $92 \%$ & $92 \%$ \\
\hline $\begin{array}{l}\text { Kesesuaian jumlah ikan dan } \\
\text { kapasitas penyimpanan }\end{array}$ & $100 \%$ & $100 \%$ & $100 \%$ & $100 \%$ & $100 \%$ & $100 \%$ \\
\hline
\end{tabular}

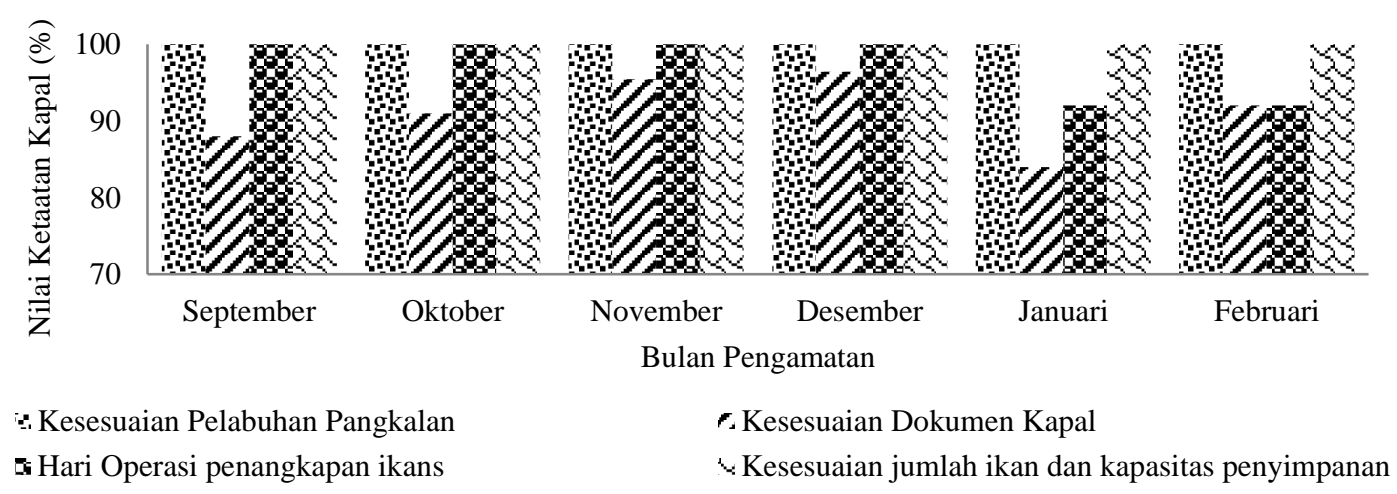

Gambar 1. Grafik persentase kepatuhan terhadap aturan dari kapal pukat cincin 30- 50 GT periode September 2018 - Februari 2019

Tabel 3. Persentase kepatuhan kapal pukat cincin >50 GT periode September 2018- Februari 2019.

\begin{tabular}{lccccccc}
\hline & \multicolumn{5}{c}{ Persentase Kepatuhan (\%) } \\
\cline { 2 - 5 } \multicolumn{1}{c}{ Uraian Aturan } & \multicolumn{5}{c}{2018} & & 2019 \\
\cline { 2 - 4 } \cline { 7 - 8 } & September & Oktober & November & Desember & & Januari & Februari \\
\hline Kesesuaian Pelabuhan Pangkalan & $100 \%$ & $100 \%$ & $100 \%$ & $100 \%$ & & $100 \%$ & $100 \%$ \\
Kesesuaian Dokumen Kapal & $85 \%$ & $88 \%$ & $96,42 \%$ & $100 \%$ & & $100 \%$ & $100 \%$ \\
Hari Operasi Penangkapan ikan & $100 \%$ & $100 \%$ & $100 \%$ & $100 \%$ & & $100 \%$ & $100 \%$ \\
Kesesuaian Jumlah Ikan Dan & $100 \%$ & $100 \%$ & $100 \%$ & $100 \%$ & & $100 \%$ & $100 \%$ \\
Kapasitas Penyimpanan & & & & & & \\
\hline
\end{tabular}




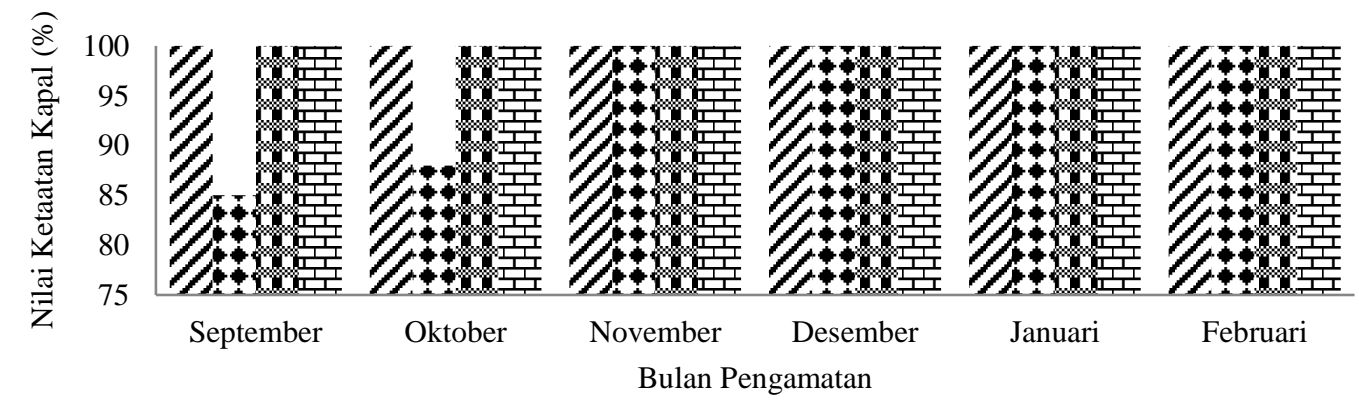

. Kesesuaian Pelabuhan Pangkalan

* Hari Operasi penangkapan ikans

: Kesesuaian Dokumen Kapal

$\llcorner$ Kesesuaian jumlah ikan dan kapasitas penyimpanan

Gambar 2. Grafik persentase kepatuhan terhadap aturan dari kapal pukat cincin >50 GT periode September 2018 - Februari 2019.

\section{Penegakan hukum terhadap ketidak-patuhan kapal pukat cincin}

Dilihat dari teknis operasional pengawasan perikanan berdasarkan KEP.143/DJPDSDKP/2012 juga memberikan pemahaman sebagai undangundang No.45 tahun 2009 yang menjelaskan tentang tingkat kepatuhan suatu kapal yang dilihat dari kesesuaian pelabuhan pangkalan, kesesuaian dokumen kapal, kesesuaian hari operasi, kesesuaian kapasitas jumlah ikan dengan kapasitas penyimpanan. Kapal yang terlambat mengurus administrasi seperti dokumen kapal tidak diijinkan untuk melakukan kegiatan penangkapan, kapal yang terlambat melapor saat tiba di pelabuhan akan mendapat sanksi tertulis yang dimateraikan 6000 dan jika dilakukan lebih dari 3 kali kapal tersebut tidak diijinkan berpangkalan atau melakukan kegiatan dipelabuhan perikanan pantai Tumumpa.

Kapal yang patuh terhadaap aturan akan diberikan apresiasi berupa pujian dan menjadi contoh sedangkan kapal yang tidak patuh diberikan sanksi seperti yang dijelaskan sebelumnya.

\section{KESIMPULAN}

Kepatuhan kapal pukat cincin diatas 30 GT dipelabuhan perikanan pantai Tumumpa berdasarkan Juknis Ditjen PSDKP No.143 tahun 2012 yang meliputi kesesuaian pelabuhan pangkalan, kelengkapan dokumen kapal, hari operasi penangkapan dan kesesuaian jumlah hasil tangkapan secara umum di kategorikan baik. Kapal yang patuh akan diberikan apresiasi sedangkan kapal yang tidak patuh diberikan sanksi sesuai dengan pelanggaran yang dibuat. Tindakan untuk efek jera diberikan oleh pengawas perikanan yaitu dengan tidak mengeluarkan SLO (surat laik operasi).

\section{Ucapan Terima Kasih}

Terimakasih bagi semua pihak yang membantu, terlebih khusus bagi PSDKP yang di koordinasikan oleh Ibu Sesi Tidajoh dan seluruh pegawai yang ada di PSDKP Tumumpa yang telah membimbing dan memberikan informasi selama penelitian.

\section{DAFTAR PUSTAKA}

Febriansyah, A.P., Luasunaung, A., Dien, H.V. 2016 Ketaatan kapal pukat cincin yang berpangkalan dipelabuhan perikanan samudera Bitung terhadap wilayah penangkapan dan yang ditetapkan menggunakan data Vessel Monitoring System. Jurnal ITPT. Vol 02, No.4, hal. 159-164, Desember 2016, p-ISSN 2337-4306, e-ISSN 2656-906X, DOI: https://doi.org/10.35800/jitpt.2.4.2016.15024

Handoko, W. 2004. Kebijakan Pengawasan Sumberdaya Kelautan Dan Perikanan. Jurnal Hukum Insternasional. Edisi Khusus. Desember 2004, Hal.107-128.

Pamungkas, R. S. 2013. Kapal perikanan (fishing Vessel). Direktorat Jederal Perikanan Tangkap, Kementrian kelautan dan perikanan

Peraturan Menteri Kelautan Dan Perikanan Republik Indonesia Nomor 1/PERMEN-KP/2017 Tentang Surat Laik Operasi Kapal Penangkap Ikan.

Peraturan Menteri No.PER.05/MEN/2007 Tentang Penyelenggara Sistem Pemantauan Kapal Perikanan.

Riduwan, 2007. Skala Pengukuran Variabel-Variabel Penelitian. Bandung: Alfabeta

Supit, E.A., Pamikiran, R.D.Ch., dan Pangalila, F.P.T. 2016 Pelaksanaan Monitoring, Controlling, Surveillance Kapal Pengangkut Ikan Di atas 30 GT di Pelabuhan Perikanan 
C.D. Yuninie dkk.

Samudera Bitung. Jurnal ITPT. Vol 02, No. 4, hal. 135139, Desember 2016, p-ISSN 2337-4306, e-ISSN 2656906X, DOI: https://doi.org/10.35800/jitpt.2.4.2016.14029
Surakhmad, Winarno. 1990. Pengantar Penelitian Ilmiah: Dasar, Metode dan Teknik. Bandung: Penerbit Tarsito. 